\title{
METODE GAS PERUNUT UNTUK EVALUASI EFISIENSI VENTILASI TAMBANG BAWAH TANAH
}

\section{A Tracer Gas Method to Evaluate Underground Mine Ventilation Efficiency}

\author{
Arif Widiatmojo ${ }^{1,{ }^{*}}$, Nuhindro Priagung Widodo ${ }^{2}$, Kyuro Sasaki $^{3}$ \\ ${ }^{1}$ Renewable Energy Research Center, National Institute of Advanced Industrial Science and Technology, AIST, \\ Japan. \\ 2 Kelompok Keahlian Teknik Pertambangan, Fakultas Teknik Pertambangan dan Perminyakan, Institut Teknologi \\ Bandung, Bandung 40132. \\ ${ }^{3}$ Department of Earth Resources Engineering, Faculty of Engineering, Kyushu University, Japan.
}

Artikelmasuk : 27-12-2020, Artikel diterima : 2021-04-27

Kata kunci:

Jaringan ventilasi tambang, gas perunut, kebocoran udara, simulasi numerik, difusi turbulensi, peluruhan konsentrasi

\section{Keywords:}

Mine ventilation network, tracer gas, air leakages, numerical simulation, turbulent diffusion, concentration decay

\begin{abstract}
ABSTRAK
Ventilasi tambang bawah tanah mempunyai peran penting untuk memastikan ketersediaan suplai udara segar untuk pekerja tambang, mesin bakar internal, melarutkan gas dan partikulat, maupun menjaga suhu dan kelembapan kelembaban udara. Desain yang tidak benar dapat menyebabkan kebocoran dan resirkulasi udara, menurunkan efisiensi energi dari sistem ventilasi secara total. Di lain hal, difusi turbulensi mengendalikan penyebaran gas dan partikulat.

Makalah ini membahas penggunaan gas perunut untuk mengevaluasi efisiensi sistem ventilasi tambang. Dengan mencocokkan hasil pengukuran lapangan dengan simulasi numerik, kuantitas suplai udara yang terbuang disebabkan karena kebocoran dapat dievaluasi. Selain itu, laju pertukaran udara di muka tambang juga di analisa berdasarkan data peluruhan gas. Sebagai hasil analisa, sekitar $53,5 \%$ udara bersih terbuang langsung melalui kipas utama. Sedangkan, laju pertukaran udara di salah satu front tambang, adalah sekitar 6,48 kali per jam.
\end{abstract}

\section{ABSTRACT}

The role of underground mine ventilation is critical to ensure an adequate supply of fresh air for mineworkers and internal combustion engines, to dilute hazardous gasses and particles, and to maintain the appropriate level of temperature and humidity. Improper mine ventilation design leads to leakages or recirculation of airflow, lowering the energy efficiency required for the total ventilation system. On the other hand, turbulent diffusion controls the spreading of gas and other particles. This paper discusses the application of tracer gas measurement to evaluate the efficiency of a mine ventilation system. The history matching of numerical simulation with the field measurement result is employed to evaluate the air leakages. Besides, the air exchange rate in a development heading was also evaluated based on the tracer gas concentration decay. The result indicates $53,5 \%$ of the fresh air supply was inefficiently wasted through direct leakages to the main fan. On the other hand, the air exchange rate from a development front was evaluated as $6,48 \mathrm{~h}^{-1}$.

${ }^{*}$ Penulis Koresponden: arif.widiatmojo@aist.go.jp

Doi : https://doi.org/10.36986/impj.v3i1.28 


\section{PENDAHULUAN}

Ventilasi tambang mempunyai peranan vital dalam porsesproses penambangan. Secara umum, ventilasi tambang bawah tanah mempunyai tiga peran utama, yaitu sebagai kontrol kuantitas, kontrol kualitas dan kontrol iklim. Dalam aplikasinya, pasokan udara ke dalam tambang harus mencukupi kebutuhan pekerja tambang, pembakaran mesin, mampu melarutkan dan membuang gas-gas berbahaya maupun partikulat lainnya, serta mengatur temperatur dan kelembapan kelembaban. Nilai minimum parameter-parameter tersebut diatur dalam regulasi pada masing-masing negara.

Untuk mengalirkan udara di dalam tambang, diperlukan main fan (kipas utama) yang dipasang di mulut tambang untuk menciptakan perbedaan tekanan dengan udara luar, sehingga aliran udara dapat terjadi. Dalam hal ini, terowongan tambang yang saling terhubung sedemikian rupa menciptakan resistance (tahanan). Proses penambangan yang dinamis ataupun perencanaan sistem ventilasi yang kurang tepat dapat menyebabkan kebocoran udara. Hal ini disebabkan karena udara selalu mencari jalur melalui terowongan dengan tahanan terkecil. Sering kali jalur ini tidak efektif karena tidak melewati area-area dimana pasokan udara lebih dibutuhkan untuk operasional tambang. Dari penelitian sebelumnya, diperkirakan kebutuhan energi untuk ventilasi tambang mencapai $50 \%$ dari total konsumsi dan sekitar $20-40 \%$ dari total biaya energi untuk penambangan (Demirel, 2018).

Metode pengukuran gas tracer (perunut) dapat diterapkan untuk mengetahui adanya kebocoran udara. Pada umumnya hasil pengukuran gas perunut berupa kurva distribusi konsentrasi terhadap waktu. Selain untuk mengetahui kebocoran udara, hasil pengukuran perunut gas juga mempunyai informasi tentang difusi turbulensi yang dialami selama perjalanan. Nilai difusi turbulensi ini, menurut beberapa penelitian sebelumnya merupakan fungsi dari beberapa parameter seperti bilangan Reynolds, diameter terowongan, dan persentase rongga pada dinding terowongan (Arpa, Widiatmojo, Widodo, \& Sasaki, 2008; Widiatmojo et al., 2015; Widiatmojo, Sasaki, Widodo, \& Sugai, 2013; Widiatmojo, Sasaki, Widodo, Sugai, et al., 2013; Widodo, Sasaki, \& Gautama, 2008).

Makalah ini mendiskusikan hasil pengukuran gas perunut yang dilakukan di tambang emas bawah tanah Cibaliung, PT. Cibaliung Sumberdaya. Melalui hasil pengukuran gas perunut, analisa dilakukan terhadap jalur kebocoran udara dan laju pertukaran udara di salah satu development heading.

\section{METODE}

\section{Konsep pengukuran gas perunut}

Dilihat dari tujuannya, pengukuran gas perunut, dapat dibagi menjadi tiga, yaitu dilution (dilusi), decay (peluruhan) dan recirculation (resirkulasi). Pengukuran gas perunut untuk dilusi dilakukan dengan melepaskan gas tertentu pada suatu posisi tertentu di hulu dan mengukur perubahan konsentrasi di suatu posisi tertentu di hilir menggunakan sensor atau monitor gas. Untuk mengetahui resirkulasi pada suatu posisi, pelepasan dan pengukuran konsentrasi dilakukan pada titik yang sama. Sedangkan peluruhan, dapat digunakan untuk mengetahui laju pergantian udara pada ruangan tertutup, sebagai contoh, development heading. Makalah ini akan memfokuskan pembahasan pada dilusi gas dan peluruhan.

Pada dasarnya, semua gas yang bersifat inert, tidak beracun dan tidak terdapat dalam konsentrasi tinggi secara natural, bisa dipakai sebagai gas perunut Salah satu gas yang umum dipakai adalah $\mathrm{SF}_{6}$ (Sulfur hexafluoride). Gas ini mempunyai massa jenis 6,12 gram/Liter atau 5 kali lebih berat dari udara pada tekanan udara 1 atmosfir.

Pelepasan gas dapat dilakukan dengan dua metode utama, yaitu pelepasan instan atau sesaat dan pelepasan kontinu. Pelepasan instan dilakukan dengan melepaskan sejumlah gas perunut dengan berat dan volume yang diketahui, secara sesaat. Gambar 1 menunjukkan persiapan dan pelaksanaan pengukuran gas perunut, dimulai dengan pengisian gas ke dalam balon, pengukuran dimensi dan berat balon yang telah terisi gas, pelepasan gas di posisi tertentu di hulu dan pengamatan konsentrasi gas di hilir. Pelepasan kontinu dilakukan dengan melepaskan gas perunut dengan jumlah konstan ataupun berubah bertahap.

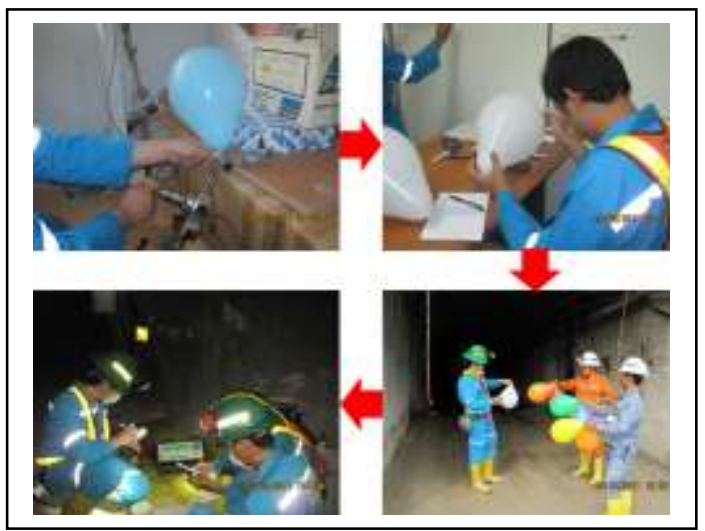

Gambar 1. Pengisian gas ke dalam balon, pengukuran berat dan dimensi balon, pelepasan gas dengan meletuskan balon dan pengamatan konsentrasi gas pada titik tertentu di dalam tambang (2011) 
Gambar 2 mengilustrasikan pengukuran gas perunut pada terowongan lurus. Monitor/sensor gas yang ditempatkan di hilir merekam perubahan konsentrasi gas terhadap waktu. Dengan menggunakan volume gas, $V\left(\mathrm{~m}^{3}\right)$, yang telah diketahui dan konsentrasi gas, C(-) sejak awal pengukuran to sampai akhir pengukuran $t_{s}$, dan dengan asumsi bahwa tidak ada gas yang hilang (bocor), maka debit aliran, $\mathrm{Q}\left(\mathrm{m}^{3} \mathrm{~s}^{-1}\right)$, dalam terowongan dapan dihitung dengan rumus:

$$
Q=V / \int_{t_{0}}^{t_{s}} C d t
$$

dimana, dt adalah interval pengamatan data konsentrasi.

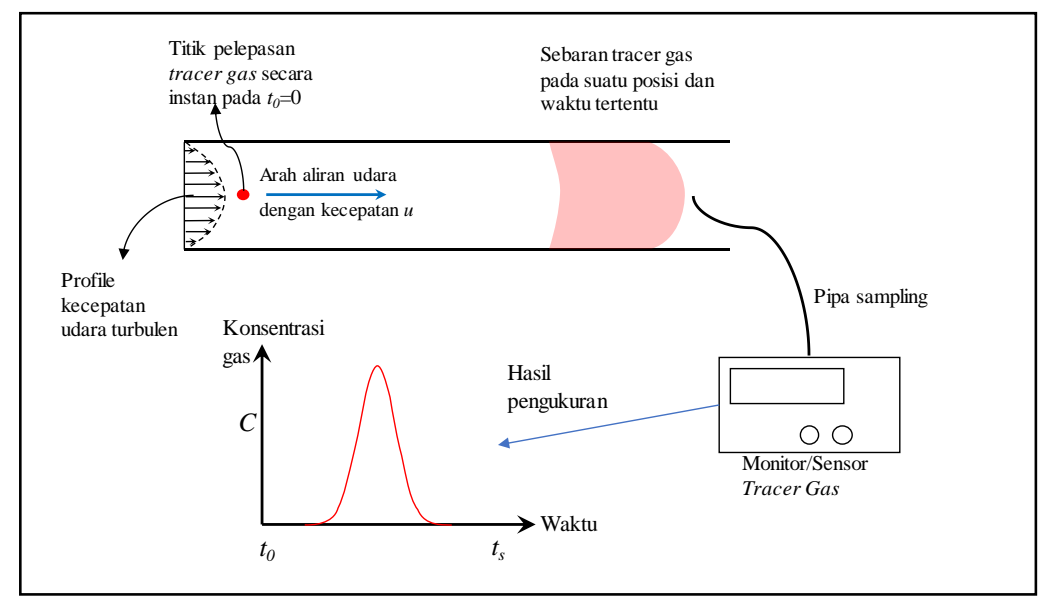

Gambar 2. llustrasi pengukuran dan pengamatan konsentrasi gas perunut pada terowongan lurus dengan metode pelepasan instan

\section{Difusi Turbulensi pada ventilasi tambang}

Secara umum, aliran udara di dalam tambang tergolong aliran turbulensi, dimana bilangan Reynolds selalu lebih besar dari $4000 \quad(R e>4000)$. Hal ini mengakibatkan fluida (udara) tambang mengalami difusi turbulensi. Difusi turbulensi adalah perpindahan massa, panas atau momentum pada suatu sistem fluida yang disebabkan oleh pergerakan acak akibat aliran turbulensi. Aliran turbulensi sendiri adalah aliran dimana fluida mengalami fluktuasi, percampuran (mixing) secara tidak beraturan. Difusi turbulensi lebih besar daripada difusi laminar.

Jika suatu gas atau massa lainnya dilepaskan pada suatu posisi di hulu, gas atau massa tersebut akan mengalami difusi ke semua arah. Untuk aliran dalam terowongan, difusi dapat direpresentasikan dalam 1dimensi, searah dengan aliran. Difusi ini disebut sebagai difusi turbulensi efektif. Namun difusi searah aliran ini juga dipengaruhi oleh difusi tegak lurus aliran, percampuran udara karena percabangan terowongan, auxiliary ventilation (ventilasi tambahan) dan sebagainya. Secara ideal, perubahan konsentrasi gas akibat aliran udara dan difusi searah aliran, dapat dinyatakan dengan rumus diferensial parsial untuk adveksi dan difusi sebagai berikut: $\partial C / \partial t+u(\partial C / \partial x)=D_{e}\left(\partial^{2} C / \partial x^{2}\right)$

Dengan $C(-)$ adalah konsentrasi gas, $D_{e}\left(\mathrm{~m}^{2} \mathrm{~s}^{-1}\right)$ adalah koeffisien difusi turbulensi efektif, $u\left(\mathrm{~ms}^{-1}\right)$ adalah kecepatan aliran udara dan $x(\mathrm{~m})$ adalah jarak dari titik pelepasan.

Distribusi konsentrasi gas pada terowongan tunggal, pada posisi tertentu di hilir, dapat dirumuskan dengan:

$C=V / 2 A \sqrt{\pi D_{e} t} \exp \left[-(x-u t)^{2} / 4 D_{e} t\right] \ldots \ldots .(3)$

Dengan $A\left(\mathrm{~m}^{2}\right)$ adalah luas penampang terowongan. Persamaan 3 di atas identik dengan fungsi distribusi probabilitas Gauss. Ilustrasi dari persamaan 3 dapat dilihat pada Gambar 3. Gambar 3 mengilustrasikan pelepasan gas pada hulu dan sebaran gas pada waktu $t_{1}, t_{2}$ dan $t_{3}(\mathrm{~s})$, dimana $t_{1}<t_{2}<t_{3}$. Bentuk kurva ideal mengikuti kurva distribusi Gauss dengan luas area bawah kurva yang sama. Gambar 4 menunjukkan perbedaan kurva distribusi konsentrasi pada waktu dan kecepatan yang sama. Perbedaan bentuk kurva disebabkan oleh perbedaan nilai $D_{e}$. 


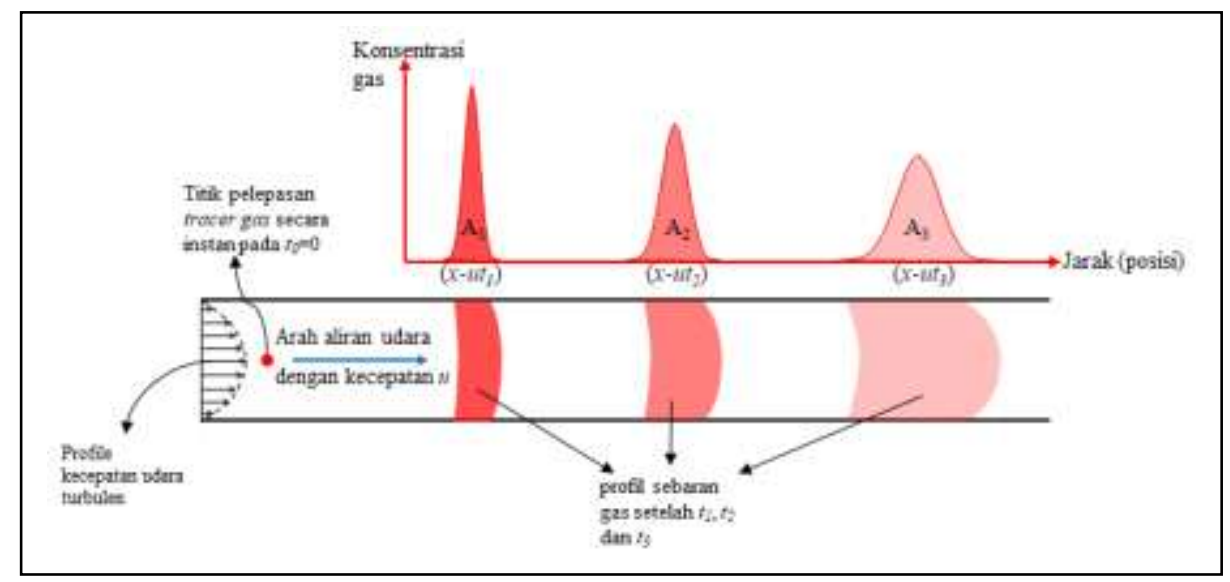

Gambar 3. llustrasi perubahan sebaran konsentrasi gas pada terowongan lurus dikarenakan efek difusi

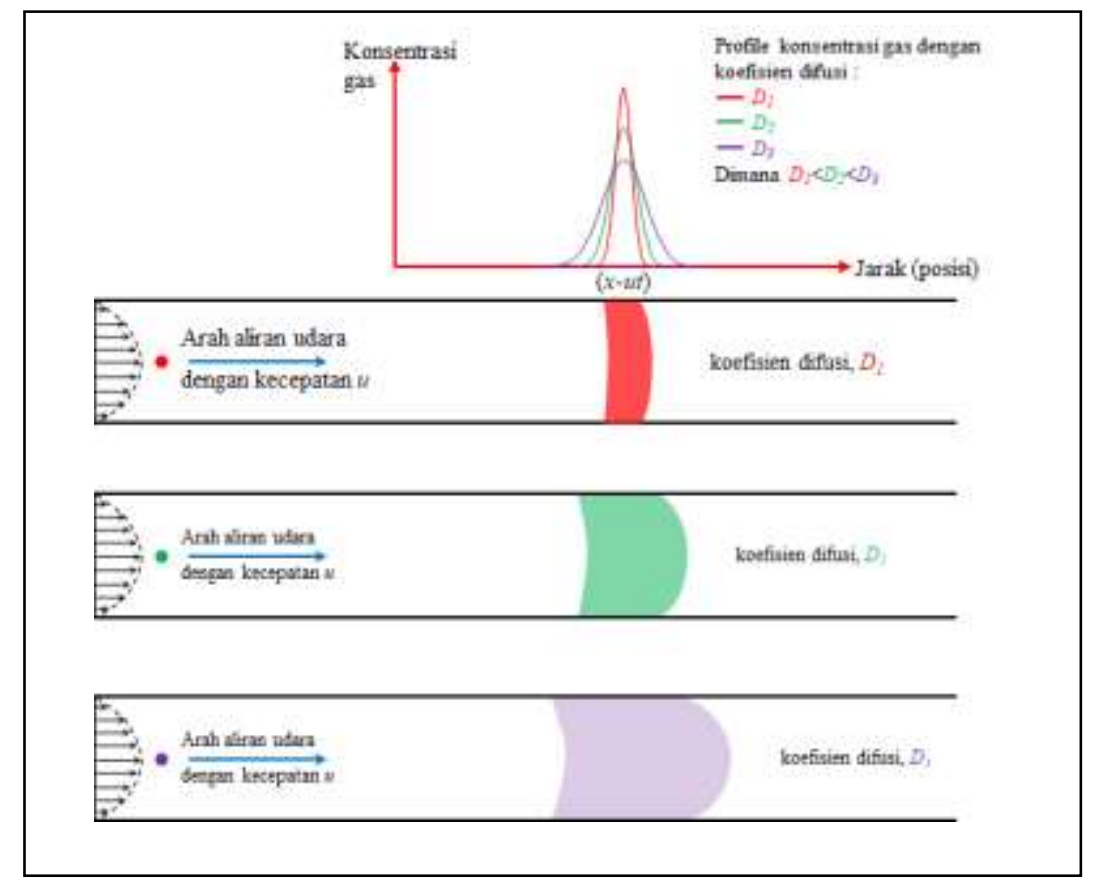

Gambar 4. llustrasi pengaruh perbedaan koefisien difusi terhadap sebaran konsentrasi gas (untuk kecepatan aliran sama)

Pada aplikasinya, data yang didapat dari pengukuran gas perunut adalah distribusi konsentrasi terhadap waktu pada titik tertentu, sedangkan persamaan 3 menghasilkan distribusi konsentrasi terhadap jarak tertentu. Untuk itu, persamaan 3 harus diubah ke dalam bentuk diskrit untuk menghitung pergerakan gas sebagaimana yang sudah dijelaskan secara detail di makalah penulis sebelumnya (Widiatmojo et al., 2015; Widiatmojo, Sasaki, Widodo, \& Sugai, 2013; Widiatmojo, Sasaki, Widodo, Sugai, et al., 2013; Widodo, Sasaki, \& Gautama, 2008).

Pada aplikasinya, jaringan ventilasi tambang merupakan jaringan kompleks dimana udara berpisah dan bertemu di persimpangan. Untuk memperhitungkan jalur ventilasi yang berbeda-beda ini, diperlukan algoritma khusus seperti yang telah dibahas pada makalah yang lain (Widiatmojo et al., 2016).

\section{Pengukuran laju pertukaran udara di front tambang}

Proses penambangan ataupun pembuatan terowongan baru berlangsung pada front tambang, yang merupakan sistem ventilasi ruang tertutup. Udara dari kipas utama tidak bisa menjangkau posisi ini dikarenakan front tambang merupakan titik buntu. Untuk itu, ventilasi tambahan harus digunakan agar 
udara dapat menjangkau front tambang. Salah satu parameter penting dalam efisiensi dan efektifitas ventilasi aktif tambahan adalah laju pertukaran udara. Laju pertukaran udara, $n_{\text {rate }}\left(\mathrm{s}^{-1}\right)$, adalah siklus volume udara yang dipindahkan dan digantikan dengan yang baru pada suatu ruangan dengan volume tertentu setiap satuan waktu. Parameter ini dapat dihitung berdasarkan peluruhan konsentrasi gas yang didapat dari pengukuran gas perunut. Pengukuran dilakukan dengan melepaskan gas perunut dengan volume tertentu di dalam ruangan dan mengukur konsentrasi gas sampai kembali ke konsentrasi awal sebelum pelepasan.

Secara umum, gas yang dilepaskan pada ruangan tertentu, akan mengalami peluruhan eksponensial apabila konsentrasi gas tersebut berkurang secara proporsional terhadap konsentrasi awal $\left(C_{0}\right)$. Secara matematis dapat diekspresikan dengan persamaan berikut:

$d C / d t=-n_{\text {rate }} C$

Dengan menata ulang dan mengintegralkan persamaan 4 di atas didapatkan:

$C(t){ }_{C_{0}}=e^{-n_{\text {rate }} t}$

Atau dalam bentuk linier:

$\ln \left({ }^{C}(t) / C_{0}\right)=-n_{\text {rate }} t$

Pengukuran gas perunut di Tambang Cibaliung, PT. Cibaliung Sumberdaya
Pengukuran gas perunut di tambang bawah tanah Cibaliung, PT. Cibaliung Sumberdaya, dilakukan pada bulan Februari-Maret 2011. Gambar 5 menunjukkan skema jaringan ventilasi tambang Cibaliung, percabangan, luas penampang terowongan serta debit udara yang diukur sesaat sebelum pelepasan gas perunut. Pada saat pengukuran, tambang masih dalam pengembangan awal. Hasil survei ventilasi mendapatkan total debit suplai udara sebesar 87,2 $\mathrm{m}^{3} \mathrm{~s}^{-1}$, dimana $84,4 \%$ berasal dari portal tambang, sedangkan sisanya berasal dari shaft Cibitung (\#1 dan \#8 pada Gambar 5). Kipas utama menggunakan kipas udara aksial berkapasitas $132 \mathrm{~kW}$ (GIA AVH224.132.6.10/50 Hz) yang terhubung ke jaringan tambang melalui shaft vertikal (titik \#23 pada Gambar 5). Gas yang digunakan adalah $\mathrm{SF}_{6}$ (Sulphur Hexafluoride) yang di pompakan ke dalam balon. Sebelum dilepaskan, berat gas dan volume balon diukur, sedangkan volume gas dihitung dengan memperhitungkan buoyancy effect (efek apung) dari gas. Pelepasan dilakukan dengan meletuskan balon. Pengamatan konsentrasi dilakukan pada beberapa titik di dalam tambang. Pencatatan konsentrasi gas dilakukan dengan menggunakan alat gas monitor khusus SF6, (Bruel Kjaer model 1402). Gas monitor ini memiliki resolusi $10 \mathrm{ppb}$ (part per billion) dan sampling interval 50-60 detik. Secara total, 6 (enam) pengukuran dilakukan, satu diantaranya pengukuran peluruhan untuk mengetahui laju pertukaran udara di dalam development heading Cross-cut 2 CikonengNorth.

Sebagian besar hasil dari penelitian ini telah dipublikasikan. Untuk pembahasan lebih lengkap hasil dari pengukuran ini, pembaca dapat mengacu pada makalah penulis lainnya (Widiatmojo, Sasaki, Widodo, \& Sugai, 2013).

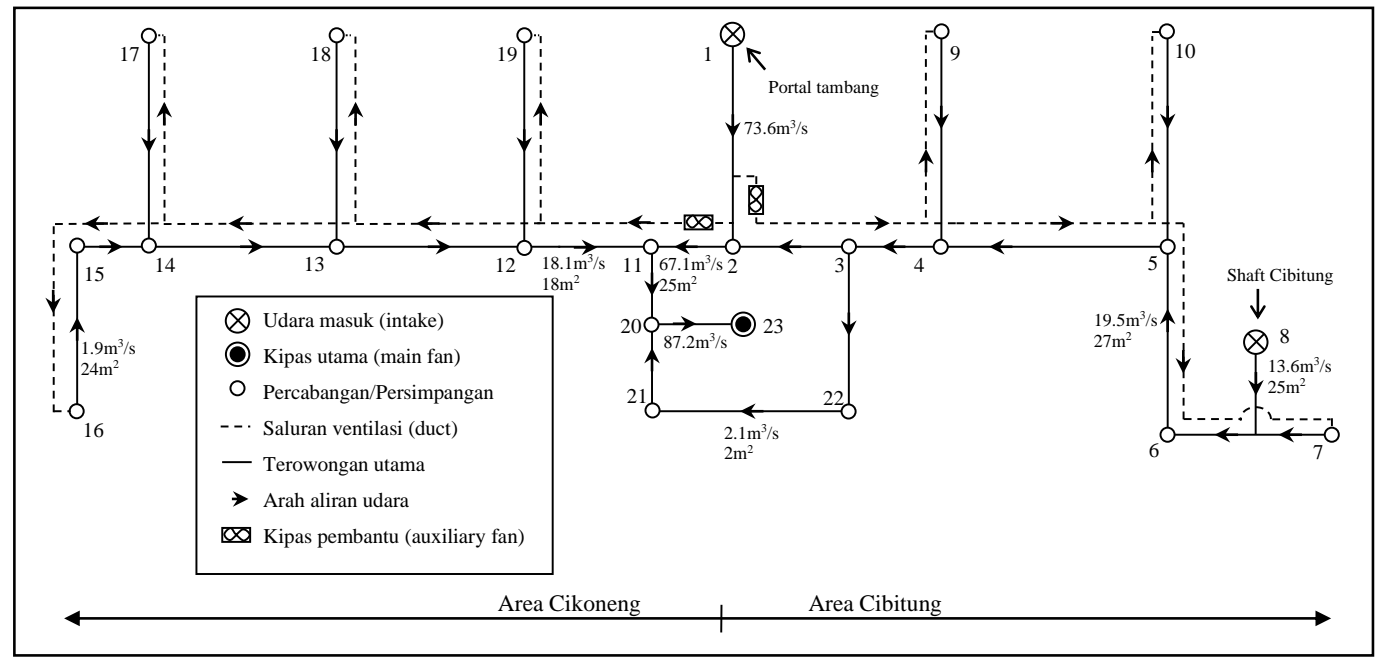

Gambar 5. Skema ventilasi tambang bawah tanah Cibaliung pada awal development, Februari-Maret 2011 (Widiatmojo et.al, 2013) 


\section{PEMBAHASAN}

\section{Analisa kebocoran udara}

Untuk menganalisa efisiensi ventilasi udara, gas perunut dilepaskan pada portal utama (titik \#1, pada Gambar 5) dan pencatatan konsentrasi di shaft kipas utama (titik \#23). Total volume $\mathrm{SF}_{6}$ yang dilepaskan adalah $0,0779 \mathrm{~m}^{3}$. Simulasi numerik dilakukan dengan terlebih dahulu mengidentifikasi jalur ventilasi sesuai hasil pengukuran debit udara tambang.

Hasil pengukuran dan simulasi dapat dilihat pada Gambar 6. Dari hasil simulasi, didapatkan dua kelompok area dengan dua puncak yang teridentifikasi sebagai kebocoran udara. Puncak pertama (area \#1 pada Gambar 6) teridentifikasi sebagai kebocoran langsung ke kipas utama melalui jalur $\# 1 \rightarrow \# 2 \rightarrow \# 11 \rightarrow \# 20 \rightarrow \# 23$ (lihat Gambar 5). Udara yang terbuang pada jalur kebocoran ini mencapai titik pengamatan pada bagian bawah shaft kipas utama, mulai dari menit ke 2,4 setelah dilepaskan, dan konsentrasi gas mencapai puncak setelah 4 menit. Udara yang terbuang melalui kelompok yang kedua (area \#2 pada Gambar 5) mulai sampai ke titik pengamatan setelah sekitar 5 menit dan konsentrasi gas mencapai puncak setelah sekitar 65 menit. Kebocoran ini teridentifikasi berasal dari saluran ventilasi yang robek di antara titik \#3 dan titik \#4 (lihat Gambar 5). Kedua puncak tersebut sampai pada titik pengamatan dalam waktu yang relatif cepat, yang menyebabkan udara tidak terdistribusi secara optimal ke front tambang.

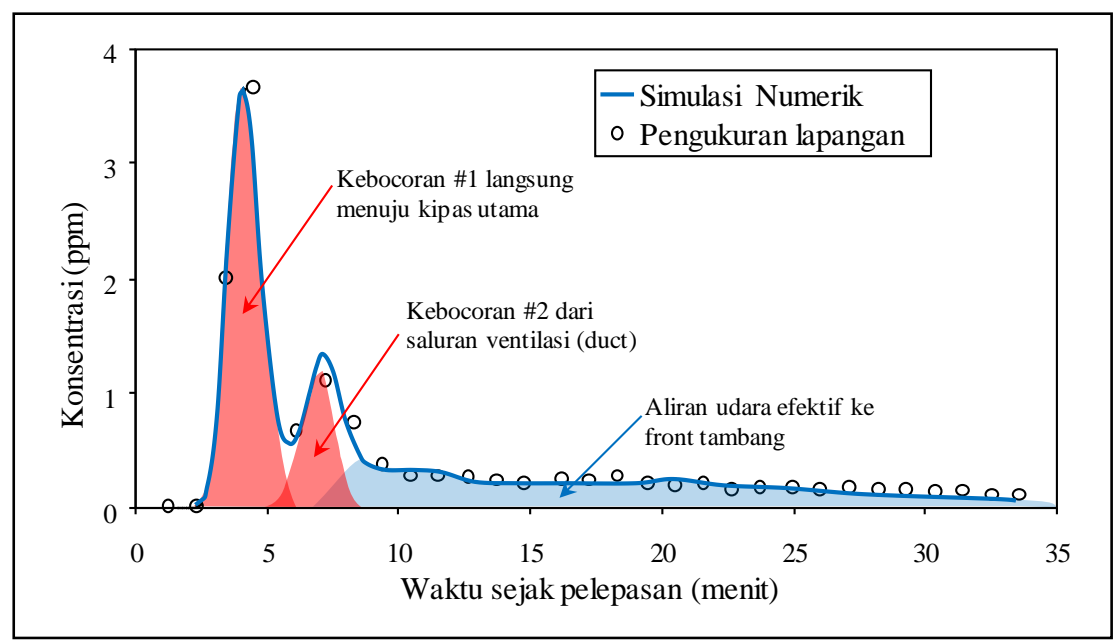

Gambar 6. Hasil pengukuran gas perunut dan simulasi numerik; hasil simulasi menunjukkan udara yang terbuang dan udara yang efektif digunakan untuk proses pengembangan front tambang

Kelompok ketiga (dengan area berwarna biru pada Gambar 6) merupakan gas perunut yang terbawa udara menuju ke beberapa front tambang. Hal ini terkonfirmasi dengan hasil simulasi numerik. Karakteristik gas perunut pada kelompok terdistribusi dalam rentang waktu yang lama dari menit ke-6,5 sampai menit ke-35. Rentang waktu yang lama disebabkan karena rute perjalanan udara yang jauh dan kecepatan udara yang relatif rendah saat kembali dari front tambang menuju ke titik pengamatan.

Melalui simulasi numerik, didapatkan bahwa, untuk memperoleh hasil simulasi yang mendekati pengukuran lapangan, untuk segmen terowongan dengan aliran udara berkecepatan rendah, nilai $D_{e}$ harus lebih besar daripada nilai $D_{e}$ untuk segmen terowongan dengan aliran udara berkecepatan lebih tinggi (Widiatmojo, Sasaki, Widodo, \& Sugai, 2013).

Dengan menghitung luas kurva pada Gambar 6, menggunakan Persamaan 1, didapatkan bahwa udara yang terbuang akibat kedua kelompok kebocoran tersebut adalah sekitar $53,5 \%$ dari total udara bersih yang masuk melalui portal utama dan shaft Cibitung (titik \#1 dan titik \#8).

\section{Analisa laju pertukaran udara di Cross-cut 2 Cikoneng-North}

Cross-cut 2 Cikoneng-North berlokasi di ujung development heading area Cikoneng (titik \#16 pada Gambar 5). Ruangan tambang ini berukuran lebar 5,23 meter, tinggi 4,94 meter dan memanjang berbentuk tabular dengan jarak sekitar 27 meter. Pengukuran dilakukan dengan melepaskan gas perunut di dekat ujung saluran ventilasi. Sebelumnya monitor gas telah dinyalakan dan merekam konsentrasi background. Sampling gas monitor dilakukan di posisi area tengah ruangan tambang, 13 meter dari muka tambang dan 9,4 meter dari ujung saluran ventilasi. Gambar 7 menunjukkan hasil pengamatan konsentrasi gas. Sesaat setelah 
dilepaskan, konsentrasi gas mencapai puncak dan seterusnya mengalami pengurangan. Untuk menganalisa nilai laju pertukaran gas $\left(n_{\text {rate }}\right)$, sesuai dengan persamaan 6 , nilai konsentrasi harus dinormalisasikan (dibagi) dengan nilai konsentrasi background $\left(\mathrm{C}_{0}=0.054 \mathrm{ppm}\right)$ dan dalam bentuk logaritmik natural $\left(\ln \left(C / C_{0}\right)\right)$. Hasil dari penghitungan tersebut disajikan dalam Gambar 8. Regresi linear (persamaan 6) dilakukan untuk mendapatkan nilai gradient linear. Didapatkan nilai $n_{\text {rate }}=6,48$ per-jam. Artinya, setiap satu jam, seluruh udara dalam Cross- cut 2 Cikoneng-North berganti selama 6,48 kali. Dengan kata lain, untuk melakukan sekali pergantian udara total dengan kondisi ventilasi saat itu, diperlukan waktu sekitar 0,15 jam atau 9,26 menit. Perlu dicatat bahwa pengukuran saat itu dilakukan hanya sekali. Faktor lain yang mempengaruhi nilai laju pertukaran udara adalah posisi pengamatan. Idealnya, pengukuran dilakukan lebih dari satu kali dengan mengambil posisi sampling yang berbeda-beda untuk mendapatkan nilai yang lebih representatif.

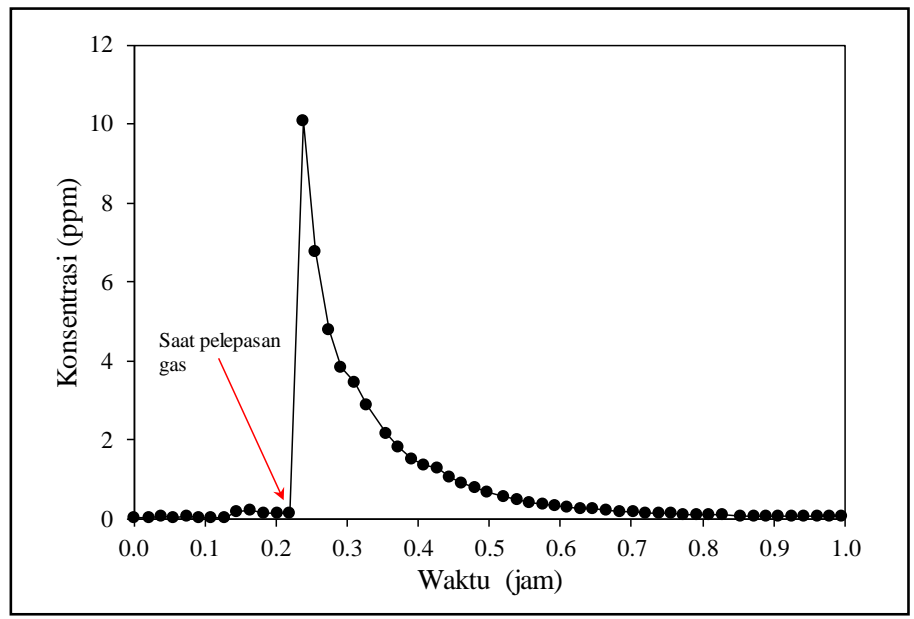

Gambar 7. Hasil pengamatan konsentrasi pada Cross-cut 2 Cikoneng North

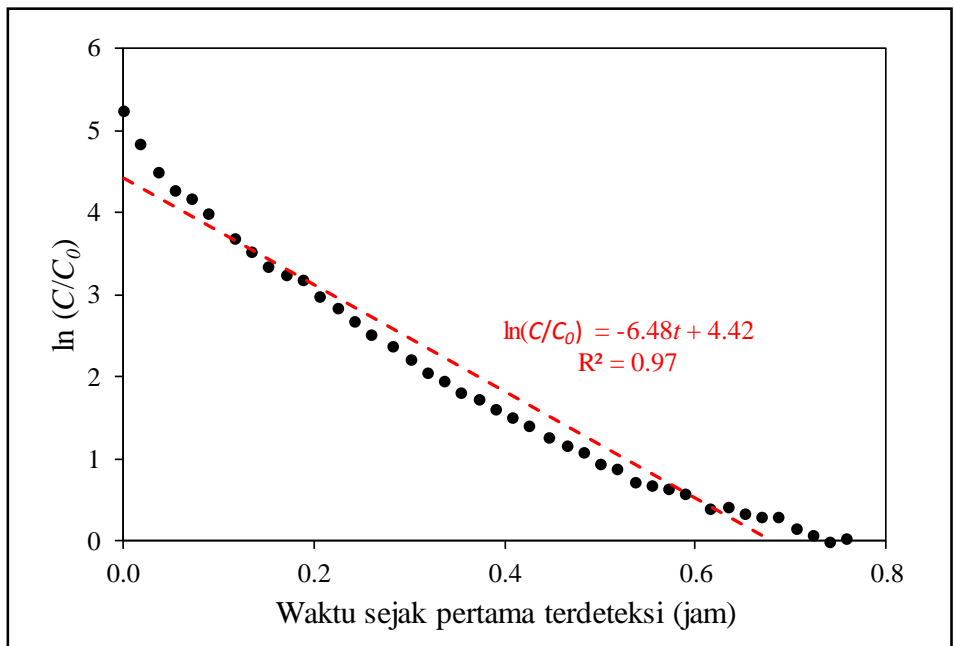

Gambar 8. Plot In $\left(C / C_{0}\right)$ terhadap waktu dan regresi linear untuk mencari gradien laju pertukaran udara dalam ruangan tertutup

\section{KESIMPULAN}

Pengukuran gas perunut telah dilakukan di tambang emas bawah tanah Cibaliung, PT. Cibaliung Sumber Daya, pada bulan Februari-Maret 2011. Analisa kebocoran udara dilakukan berdasarkan hasil pengukuran dan simulasi numerik. Didapatkan bahwa $53,5 \%$ udara bersih yang seharusnya terdistribusi ke area development terbuang langsung melalui kipas utama dikarenakan posisi kipas utama dan tekanan yang besar. Perawatan dari saluran udara (ventilation duct) mutlak diperlukan untuk mencegah kebocoran udara.

Dari hasil pengukuran gas perunut di Cross-Cut 2 Cikoneng-North, dapat disimpulkan bahwa laju pertukaran udara pada lokasi tersebut adalah 6,48 kali per jam. Namun, untuk mendapatkan hasil yang lebih representatif, hendaknya pengukuran dilakukan lebih 
dari satu kali dengan mengambil posisi sampling yang bervariasi. Sehingga rata-rata nilai laju pertukaran udara dapat di-evaluasi.

\section{UCAPAN TERIMA KASIH}

Ucapan terima kasih kepada Bapak Haris Yusuf, Bapak Johannes Sinaga, Bapak Ramdhana, dan juga segenap direksi, engineer, dan karyawan PT. Cibaliung Sumberdaya, atas dukungan dan bantuan selama pelaksanaan pengukuran gas perunut di tambang emas Cibaliung.

\section{DAFTAR PUSTAKA}

Arpa, G., Widiatmojo, A., Widodo, N. P., \& Sasaki, K. (2008). Tracer gas measurement and simulation of turbulent diffusion in mine ventilation airways. Journal of Coal Science and Engineering (China), 14, 523-529. https://doi.org/10.1007/s12404-008-0401-x

Demirel, N. (2018). Energy-Efficient Mine Ventilation Practices. In Awuah-Offei K. (Ed.) (pp. 287-299). https://doi.org/10.1007/978-3-319-54199-0_16

Widiatmojo, A., Sasaki, K., Sugai, Y., Suzuki, Y., Tanaka, H., Uchida, K., \& Matsumoto, H. (2015). Assessment of air dispersion characteristic in underground mine ventilation: Field measurement and numerical evaluation. Process Safety and Environmental Protection, 93(April), 173-181. https://doi.org/10.1016/j.psep.2014.04.001

Widiatmojo, A., Sasaki, K., Widodo, N. P., \& Sugai, Y. (2013). Discrete Tracer Point Method to Evaluate Turbulent Diffusion in Circular Pipe Flow. Journal of Flow Control Measurementand Visualization, 1(2), 57-68.

Widiatmojo, A., Sasaki, K., Widodo, N. P., Sugai, Y., Sahzabi, A. Y., \& Nguele, R. (2016). Predicting gas dispersion in large scale underground ventilation: $\mathrm{A}$ particle tracking approach. Building and Environment, $\quad 95, \quad 171-181$. https://doi.org/10.1016/j.buildenv.2015.07.025

Widiatmojo, A., Sasaki, K., Widodo, N. P., Sugai, Y., Sinaga, J., \& Yusuf, H. (2013). Numerical simulation to evaluate gas diffusion of turbulent flow in mine ventilation system. International Journal of Mining Science and Technology, 23(3), 349-355. https://doi.org/10.1016/j.jimst.2013.05.004

Widodo, N. P., Sasaki, K., \& Gautama, R. S. (2008). Mine ventilation measurements with tracer gas method and evaluations of turbulent diffusion coefficient. International Journal of Mining, Reclamation and Environment, 22(1), 60-69. https://doi.org/10.1080/17480930701474869 